\section{Leonardite Influences Zinnia and Marigold Growth}

\author{
Jerry B. Dudley ${ }^{1}$, Alton J. Pertuit, Jr. ${ }^{2}$, and Joe E. Toler ${ }^{3}$ \\ Clemson University, Clemson, SC 29634
}

Additional index words. humic acid, fulvic acid, IHSS standard

\begin{abstract}
The addition of leonardite may increase, or at least maintain, production quality of ornamental plants and permit reductions in fertilizer inputs. The objective of this study was to determine the effects of a Utah-mined leonardite on early stages of zinnia (Zinnia elegans Jacq. 'Small World Pink') and marigold (Tagetes patula L. 'Janie Yellow') growth. The Utah leonardite was characterized by comparing it to the International Humic Substances Society's leonardite standard. Zinnia and marigold seedlings and transplants were grown in sand and 1 sand : 1 peat media (by volume) with leonardite additions of $0 \%, 3.125 \%, 6.25 \%$, and $12.5 \%$. Both species showed positive growth responses to $3.125 \%$ leonardite in each medium compared to fertilizer alone. Plant responses to increased leonardite additions were generally quadratic, and optimal leonardite levels were estimated. For growing zinnias, optimal conditions were determined to be $7.5 \%$ leonardite in a sand medium for seedlings and $8 \%$ in a sand-peat mixture for transplants. A sand-peat medium containing $7 \%$ leonardite was determined to be optimal for growing marigold seedlings and transplants. Addition of leonardite to growing medium offers promise for reducing fertilizer use during production of some ornamental plants.
\end{abstract}

Leonardite is a naturally occurring, brownblack, oxidized form of lignite coal (O'Donnel, 1973), and it is primarily comprised of humic substances (Schnitzer and Khan, 1972). A reference standard leonardite has been established by the International Humic Substances Society (IHSS) (MacCarthy et al., 1981). Some commercially available fertilizers and additives already contain refined leonardite or leonardite extractants. Alarge natural reserve of leonardite exists in the United States in North Dakota, South Dakota, Utah, New Mexico, and Texas (Jackson, 1993).

With adequate mineral nutrition, root and shoot growth stimulation has been commonly observed in plants treated with humic substances (Bryan, 1976; Pertuit et al., 2001; Rauthan and Schnitzer, 1981; Reynolds et al., 1995; Tan and Nopamornbodi, 1979). Leonardite has promoted root growth in geranium [Pelargonium $\times$ hortorum (L.) H. Bail.] cuttings (O'Donnell, 1973) and overall yield in wine grapes (Vitis vinifera L.), cotton (Gossypium hirsutum L.) (Brownell et al., 1987), and corn (Zea mays L.) (Duplessis and MacKinzie, 1983). However, excessive concentrations of humic substances have inhibited growth (Ayuso et al., 1996; Bryan, 1976; Pertuit et al., 2001; Rauthan and Schnitzer, 1981; Reynolds et al., 1995).

Most of the organic carbon contained in soil is insoluble; however, a small fraction is often water soluble and has not yet leached. The organic material capable of being dissolved

Received for publication 19 Dec. 2002. Accepted for publication 27 May 2003.

${ }^{1}$ Former Graduate Research Assistant, Dept. of Horticulture. Present address: NC State Univ Coop. Ext., Pender County Ctr., 801 S. Walker St., Burgaw, NC 28425.

${ }^{2}$ Dept. of Horticulture.

${ }^{3}$ Dept. of Applied Economics and Statistics. E-mail address:jtoler@clemson.edu and not sorbed to the solid particles is defined as water-extractable organic carbon (WEOC) (Tao and Lin, 2000). Many of the positive effects of humic substances have been correlated with indirect effects such as enhanced nutrient uptake (Adani et al., 1998; David et al., 1994; Duplessis and MacKinzie, 1983; Rauthan and Schnitzer, 1981); however, the dissolved fraction may have the potential to directly influence plant growth. Using ${ }^{14} \mathrm{C}$-labeled humic substances, Vaughan and Ord (1985) illustrated that fulvic acid (FA) and humic acid (HA) were taken up by pea (Pisum sativum L.) plants. Absorption increased when a two percent sucrose solution was added, but more FA than HA was found in plant tissue. Fuehr and Sauerbek (1967) reported that low molecular weight degradation products of humus were transported into physiologically active plant parts, but humic acids were not.

With continuous growth of the horticultural industry, there are environmental concerns associated with increased fertilizer use. The addition of leonardite or other humic substances could increase, or at least maintain, production quality of ornamental plants with reduced fertilizer inputs. Specific leonardite recommendations are difficult to make because of variations in leonardite itself, differential responses of species, and various fertilizer regimes that may be employed (Vaughan and Malcolm, 1985). Using two commercially-important species (zinnia and marigold), the research objectives were to: 1) determine if addition of leonardite affects growth; 2) determine if enhanced growth resulting from addition of fertilizer can be enhanced further by addition of leonardite; 3 ) compare some chemical and physical properties of the leonardite utilized in these experiments with the IHSS leonardite standard; and 4) measure the level of water-extractable fulvic acid (WEFA) in the leonardite used in these experiments.
Leonardite characterization. To characterize the leonardite material employed in these tests, a sample of the IHSS Leonardite standard was obtained (bulk source Gascoyne leonardite, IHSS, Gascoyne, N.D.) and analyzed along with our Utah leonardite (Live Earth Products, Emery, Utah) as described by Pertuit et al. (2001). A lab test to simulate constant plant watering in an attempt to exhaust the leonardite samples of WEOC was conducted by mixing $10 \mathrm{~g}$ of leonardite with $50 \mathrm{~mL}$ of distilled deionized water. Each sample (three replicates for each leonardite source) was mechanically shaken for $1 \mathrm{~h}$ and allowed to stand for $2 \mathrm{~d}$; the water extract was removed using a 0.45 $\mu \mathrm{m}$ pore filter; and $50 \mathrm{~mL}$ of water was again added to each sample. This was repeated every $2 \mathrm{~d}$ for $30 \mathrm{~d}$. Each water extract was treated with $6 \mathrm{~m}$ of $\mathrm{HCl}$ to precipitate $\mathrm{HA}$ (Schnitzer, 1982). TotalFA was determined as described by Pertuit et al. (2001). Results were subjected to analysis of variance (ANOVA) to compare the leonardite sources. An exponential model was fitted using nonlinear least squares to characterize the change in WEFA over time.

Procedure. Four experiments were conducted to evaluate zinnia (Zinnia elegans Jacq. 'Small World Pink') and marigold (Tagetes patula L. 'Janie Yellow') (Geo W. Park Seed Co., Greenwood, S.C.) growth responses in growing media containing raw leonardite and fertilizer. The two growing media used were sand and 1 sand : 1 peat (by volume), (Play Sand Co., Quikrete Co., Atlanta, Ga.; Southland Sphagnum Peat Moss, Southern Importers, Greensboro, N.C.) and leonardite was incorporated at rates of $0 \%, 3.125 \%, 6.25 \%$, and $12.5 \%$ (by volume). Fertilizer applications of $150 \mathrm{ppm} \mathrm{N}(20 \mathrm{~N}-4.3 \mathrm{P}-16.6 \mathrm{~K})$ were made once per week. The 10 treatments consisted of the eight combinations of two growing media and four leonardite levels with fertilizer and a control without leonardite or fertilizer for each growing medium. Pulverized dolomitic limestone was preplant-incorporated at a rate of $1 \mathrm{~g}$ of lime per $18.04 \mathrm{~g}$ of leonardite in the sand medium and an additional $1 \mathrm{~g}$ of lime per $26.75 \mathrm{~g}$ of peat in the sand-peat medium and allowed to equilibrate for $10 \mathrm{~d}$ in order to adjust the $\mathrm{pH}$ to 6.0 for each treatment. The leonardite employed in these tests was from a Utah mine, and its texture is similar to washing powder. Data were subjected to ANOVA, and single degree-of-freedom contrasts were used to examine planned comparisons among treatments and to evaluate relationships between plant responses and leonardite levels using linear and quadratic polynomial contrasts $(\alpha=0.05)$. For quadratic relationships, optimal leonardite levels were determined by differentiating the fitted equations.

Zinnia andmarigold seedlings. This experiment was conducted to determine effects of leonardite on germination and early stages of zinnia and marigold growth. The treatments were arranged in a randomized complete-block design with three replications and five seedlings per replicate. Zinnia and marigold seeds were sown into plug trays (cell vol.: $21.3 \mathrm{~cm}^{3}$ ) 
on 11 July and grown in a greenhouse with a minimum temperature of $15.5^{\circ} \mathrm{C}$. Small cotton plugs were placed in the bottom of each plug cell to prevent the growing medium from washing through the bottom holes. Initially, water was applied until the growing media was thoroughly saturated. Plants were then misted as needed, with frequency of watering the same for all treatments. Fertilizer applications were made once per week beginning 20 July. Data were recorded at harvest on 9 Aug.

Zinnia and marigold transplants. This experiment was conducted to determine effects of leonardite on postplug-stage zinnia and marigold growth using seedlings grown as previously described. On 8 Aug., seedlings were transplanted into equivalent growing media in cell packs (cell vol.: $124.4 \mathrm{~cm}^{3}$ ). Plants were arranged in a randomized complete-block design with three replications. Two paper coffee filters were trimmed and placed in the bottom of each cell to prevent the growing medium from washing through the bottom holes. Water and fertilizer were applied as described for zinnia and marigold seedlings. Data were recorded at harvest on 29 Aug.

\section{Results and Discussion}

Leonardite characterization. Physical and chemical properties of Utah-mined leonardite were compared to the IHSS Standard Leonardite (Table 1). Lab tests revealed that WEFA were released from both leonardite sources. Humic acid precipitates were not formed when the $\mathrm{pH}$ of this aqueous solution was adjusted to below 2. The greatest amount of WEFA was released from each leonardite source on day 2 , and the amount of released WEFA decreased at a decreasing rate for each source over the 30-d sampling period (Fig. 1). However, based on the optimal levels of fulvic acid reported by Chen and Aviad (1990) for enhancing root and shoot growth, the leonardite levels used in this study $(3.125 \%, 6.25 \%$, and $12.5 \%$ per volume of growing medium) should supply adequate levels of fulvic acid.

Zinnia seedlings. The addition of fertilizer to sand and sand-peat growing media without leonardite increased zinnia seedling growth (Table 2). Height increased $83 \%$ and $95 \%$, fresh shoot weight increased $182 \%$ and $186 \%$, fresh root weight increased $175 \%$ and $108 \%$, dry shoot weight increased $158 \%$ and $157 \%$, and dry root weight increased $240 \%$ and $56 \%$ in sand and sand-peat media, respectively.

For sand and sand-peat growing media, the addition of leonardite influenced seedling height, fresh shoot and root weight, and dry shoot and root weight (Fig. 2). In most cases, the addition of leonardite resulted in increased growth up to the $6.25 \%$ level followed by reduced growth for the highest leonardite level $(12.5 \%)$. This trend is often observed when humic substances are incorporated into the growing medium (Pertuit et al., 2001; Ayuso et al., 1996; Rauthan and Schnitzer, 1981; Reynolds et al., 1995; Tan and Nopamornbodi, 1979). Since an optimum level of leonardite was indicated for each growth measure over the range of leonardite levels examined, quadratic models adequately characterized $\left(r^{2}=0.68-0.99\right)$ the effect of leonardite on plant growth.

The optimal level of leonardite estimated from the fitted quadratic equation for each growth measure ranged from $6.1 \%$ to $7.0 \%$ for the sand-peat medium and from $7.1 \%$ to $8.4 \%$ for the sand medium. Predictions based on these optimal levels generally reflect greater response to leonardite for the sand medium than for the sand-peat mixture, possibly due to some HA/FA compounds supplied by the peat. However, a higher percentage of leonardite is necessary to achieve optimal zinnia seedling growth with sand growing-medium. Based on the fitted equations for the sand medium, optimal leonardite levels would increase height

Table 1. Physical and chemical properties of International Humic Substances Society (IHSS) Standard leonardite and Utah-mined leonardite.

\begin{tabular}{lccccccc}
\hline $\begin{array}{l}\text { Leonardite } \\
\text { source }\end{array}$ & $\begin{array}{c}\text { Moisture } \\
(\%)\end{array}$ & $\mathrm{pH}$ & $\begin{array}{c}\text { CEC } \\
(\mathrm{meq} / 100 \mathrm{~g})\end{array}$ & $\begin{array}{c}\text { Base } \\
\text { saturation } \\
(\%)\end{array}$ & $\begin{array}{c}\text { Total organic } \\
\text { matter } \\
(\%)\end{array}$ & $\begin{array}{c}\text { Humic acid } \\
\text { extracted } \\
(\%)\end{array}$ & $\begin{array}{c}\text { Fulvic acid } \\
\text { extracted } \\
(\%)\end{array}$ \\
\hline Standard & 11.85 & 3.58 & 110.5 & 29.8 & 65.5 & 23.4 & 0.74 \\
Utah & 13.07 & 3.90 & 114.8 & 36.7 & 55.0 & 22.2 & 0.51 \\
\hline
\end{tabular}

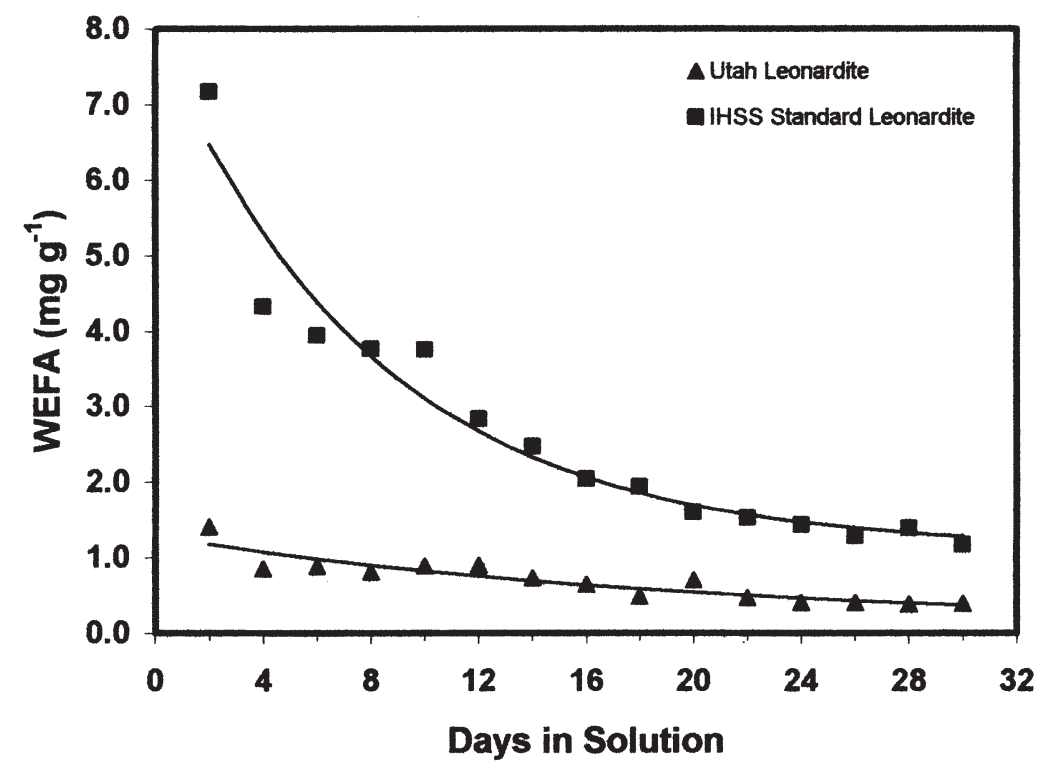

Fig. 1. Amount (mg) of water-extractable fulvic acid (WEFA) derived from one g of International Humic Substances Society (IHSS) leonardite standard and Utah-mined leonardite. Nonlinear least squares equations: Utah WEFA $=0.6965+5.8017 \mathrm{e}^{-0.053 * \text { day }}$, Standard WEFA $=5.5794+34.3303 \mathrm{e}^{-0.1236 * \text { day }}$.

Table 2. The effects of fertilizer $(20 \mathrm{~N}-4.3 \mathrm{P}-16.6 \mathrm{~K})$ applications at a rate of $150 \mathrm{ppm} \mathrm{N}$ to sand or 1 sand : 1 peat (by volume) growing medium on zinnia and marigold seedling and transplant growth.

\begin{tabular}{|c|c|c|c|c|c|c|c|}
\hline & \multirow{2}{*}{$\begin{array}{l}\text { Growing } \\
\text { medium }\end{array}$} & \multirow[b]{2}{*}{ Fertilizer } & \multirow{2}{*}{$\begin{array}{c}\text { Height } \\
(\mathrm{cm})\end{array}$} & \multicolumn{2}{|c|}{ Fresh wt $(\mathrm{g})$} & \multicolumn{2}{|c|}{ Dry wt (g) } \\
\hline & & & & Shoot & Root & Shoot & Root \\
\hline \multirow[t]{4}{*}{ Zinnia seedlings } & Sand & None & 2.20 & 0.17 & 0.12 & 0.031 & 0.010 \\
\hline & & + & 4.03 & 0.48 & 0.33 & 0.080 & 0.034 \\
\hline & Sand-peat & None & 2.38 & 0.22 & 0.24 & 0.037 & 0.025 \\
\hline & & + & 4.64 & 0.63 & 0.50 & 0.095 & 0.039 \\
\hline \multirow[t]{4}{*}{ Zinnia transplants } & Sand & None & 3.01 & 0.22 & 0.15 & 0.032 & 0.014 \\
\hline & & + & 10.08 & 2.15 & 1.10 & 0.304 & 0.085 \\
\hline & Sand-peat & None & 4.17 & 0.36 & 0.24 & 0.057 & 0.027 \\
\hline & & + & 11.87 & 2.24 & 1.44 & 0.322 & 0.120 \\
\hline \multirow[t]{4}{*}{ Marigold seedlings } & Sand & None & 1.74 & 0.04 & 0.03 & 0.006 & 0.003 \\
\hline & & + & 3.72 & 0.31 & 0.08 & 0.029 & 0.007 \\
\hline & Sand-peat & None & 2.95 & 0.15 & 0.11 & 0.021 & 0.011 \\
\hline & & + & 5.33 & 0.57 & 0.26 & 0.054 & 0.026 \\
\hline \multirow[t]{4}{*}{ Marigold transplants } & Sand & None & 2.54 & 0.07 & 0.03 & 0.010 & 0.003 \\
\hline & & + & 7.71 & 1.72 & 0.55 & 0.169 & 0.034 \\
\hline & Sand-peat & None & 5.56 & 0.35 & 0.12 & 0.039 & 0.012 \\
\hline & & + & 8.67 & 2.52 & 0.69 & 0.246 & 0.048 \\
\hline \multicolumn{2}{|c|}{ Contrast: Fertilizer vs. no fertilizer ${ }^{2}$} & & & \multicolumn{4}{|c|}{ Probability } \\
\hline \multicolumn{2}{|l|}{ Zinnia seedlings } & & $<0.001$ & $<0.001$ & $<0.001$ & $<0.001$ & 0.006 \\
\hline \multicolumn{2}{|l|}{ Zinnia transplants } & & $<0.001$ & $<0.001$ & $<0.001$ & $<0.001$ & $<0.001$ \\
\hline \multicolumn{2}{|l|}{ Marigold seedlings } & & $<0.001$ & $<0.001$ & $<0.001$ & $<0.001$ & $<0.001$ \\
\hline \multicolumn{2}{|l|}{ Marigold transplants } & & $<0.001$ & $<0.001$ & $<0.001$ & $<0.001$ & $<0.001$ \\
\hline
\end{tabular}

${ }^{\text {z}}$ Consistent for each growing medium. 
$36 \%$, fresh shoot weight $61 \%$, fresh root weight $154 \%$, dry shoot weight $58 \%$, and dry root weight $103 \%$ compared to no leonardite. For the sand-peat growing medium, increases of $12 \%$ for height, $18 \%$ for fresh shoot weight, $43 \%$ for fresh root weight, $36 \%$ for dry shoot weight, and $51 \%$ for dry root weight would be expected for the optimal leonardite levels.

These results help explain the interaction between media type and leonardite level detected in the ANOVA. The interaction may be attributable to differential changes in the physical or chemical properties of the growing media with increasing levels of leonardite. Changes to basic physical or chemical properties of the media could be detrimental to plant growth and result in the reductions observed when $12.5 \%$ leonardite was used.

Zinnia transplants. The addition of fertilizer to sand and sand-peat growing media without leonardite greatly increased the growth of zinnia transplants (Table 2). Height increased $235 \%$ and $185 \%$, fresh shoot weight increased $877 \%$ and $522 \%$, fresh root weight increased $633 \%$ and $500 \%$, dry shoot weight increased $850 \%$ and $465 \%$, and dry root weight increased $507 \%$ and $344 \%$ in sand and sand-peat media, respectively.

Zinnia transplants grown in sand medium did not respond as well as zinnia seedlings to leonardite additions. No response to leonardite was detected for height or shoot growth of zinnia transplants (Fig. 3); however, leonardite did enhance root growth in sand medium with increases in response observed up to $6.25 \%$ leonardite followed by a reduction at $12.5 \%$. The optimal leonardite level was determined to be $6.4 \%$ and $7.0 \%$ for fresh and dry root weight, respectively. Compared to no leonardite, the optimal levels would be expected to increase fresh root weight $50 \%$ and dry root weight $40 \%$. Zinnia transplants grown in sand-peat medium continued to benefit from leonardite addition (Fig. 3). Of the growth measures observed, only dry root weight failed to respond. Optimal leonardite levels ranged from $6.6 \%$ to $8.5 \%$ for growth measures of zinnia transplants in the sand-peat medium. Increases of $18 \%$ for height, $28 \%$ for fresh shoot weight, $27 \%$ for fresh root weight, and $33 \%$ for dry shoot weight would be expected for the optimal leonardite levels using the sand-peat growing medium. Fitted quadratic models adequately characterized $\left(r^{2}=0.78-0.99\right)$ the effect of leonardite on growth of zinnia transplants.

Compared to the sand only medium, higher water holding and cation exchange capacities for the sand-peat mixture provided increased amounts of water and nutrients and enabled the zinnia transplants to continue growing. Because the above-optimal leonardite level resulted in reduced growth of roots for sandgrown plants as well as roots and shoots of sand-peat grown plants, the high leonardite level may be toxic to zinnias.

Marigold seedlings. The addition of fertilizer to sand and sand-peat growing medium without leonardite increased marigold seedling growth (Table 2). Height increased $114 \%$ and
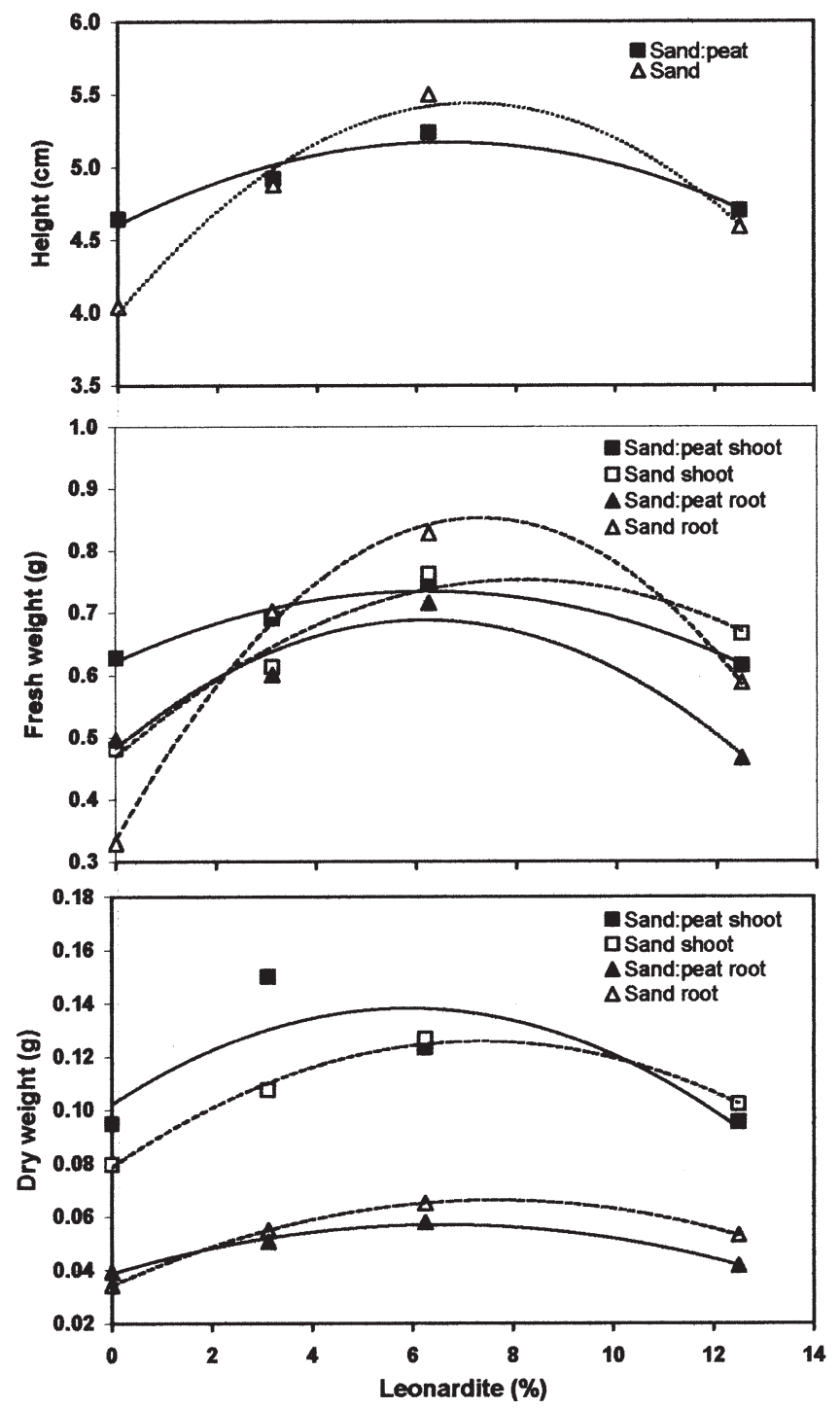

Fig. 2. Effects of Utah-mined leonardite levels on height, fresh shoot and root weight, and dry shoot and root weight of zinnia seedlings in a sand or a 1 sand : 1 peat (by volume) growing medium with fitted quadratic relationships $(P<0.05)$.
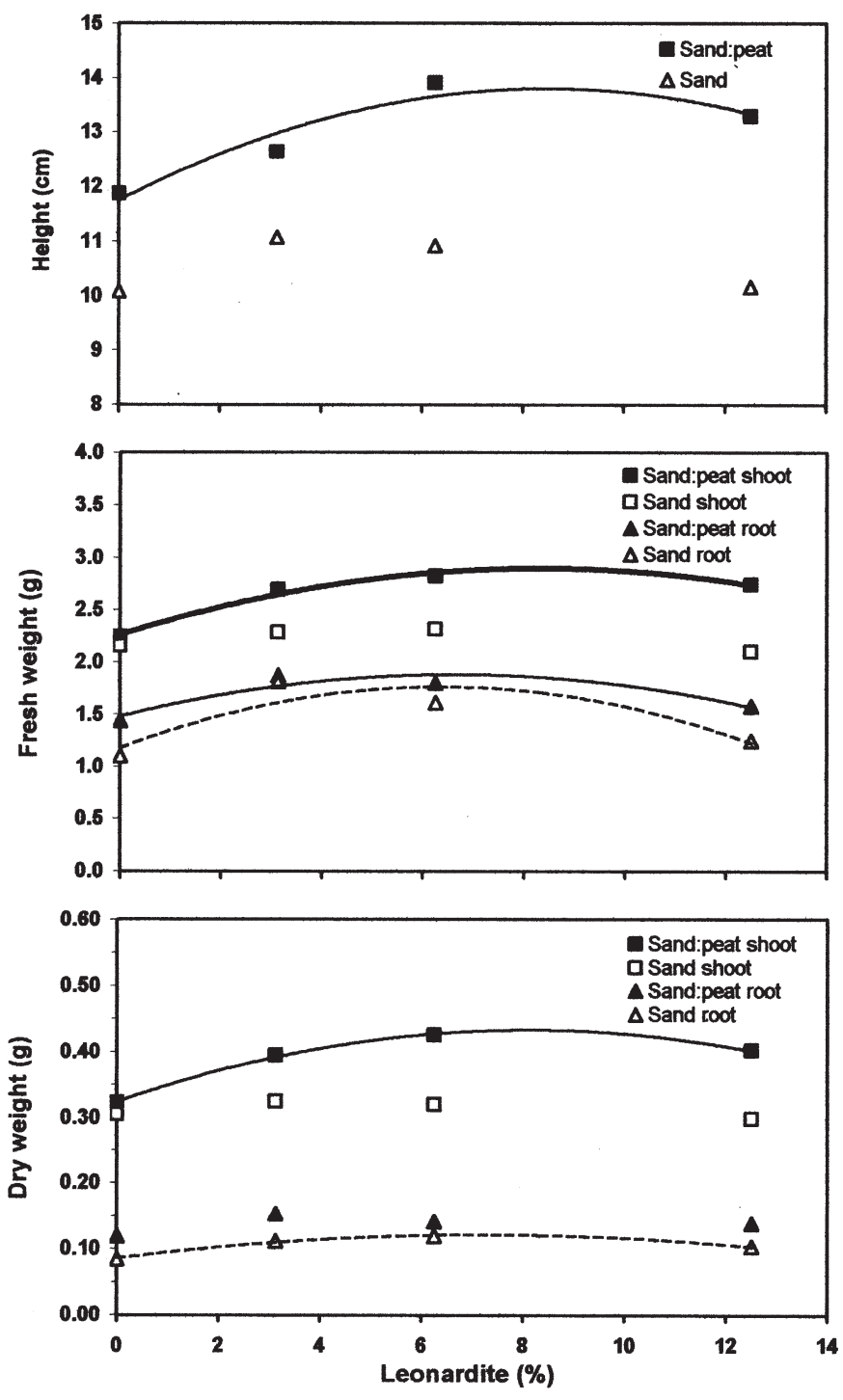

Fig. 3. Effects of Utah-mined leonardite levels on height, fresh shoot and root weight, and dry shoot and root weight of zinnia transplants in a sand or a 1 sand : 1 peat (by volume) growing medium with fitted quadratic relationships when $P<0.05$, otherwise lines are not shown. 
$81 \%$, fresh shoot weight increased $675 \%$ and $280 \%$, fresh root weight increased $166 \%$ and $136 \%$, dry shoot weight increased $383 \%$ and $157 \%$, and dry root weight increased $133 \%$ and $57 \%$ in sand and sand-peat media, respectively.

For the sand growing medium, marigold growth increased with leonardite additions up to $6.25 \%$ and then, except for dry root weight, declined for $12.5 \%$ leonardite (Fig. 4). Optimal leonardite levels based on fitted quadratic equations $\left(r^{2}=0.71-0.99\right)$ ranged from 8.4 to 13.3 for the different growth measures. The optimal levels determined for marigold seedlings grown in sand medium are generally higher than for zinnia seedlings. Based on the fitted equations, optimal leonardite levels would be expected to increase height $66 \%$, fresh shoot weight $79 \%$, fresh root weight $305 \%$, dry shoot weight $110 \%$, and dry root weight $296 \%$ compared to no leonardite.

Fresh shoot and root weight and dry shoot weight of marigold seedlings grown in the sand-peat mixture followed the usual pattern of increasing response for leonardite additions up to $6.25 \%$ and then declining for the high level (Fig. 4). Optimal leonardite levels for these growth measures ranged from $5.7 \%$ to $8.33 \%$, and increases of $22 \%$ for fresh shoot weight, $27 \%$ for fresh root weight, and $38 \%$ for dry shoot weight would be expected for the optimal leonardite levels. Addition of leonardite to the sand-peat growing medium did not influence marigold seedling height but resulted in a linear reduction in root dry weight (Fig. 4).

As observed for zinnia seedlings, marigold seedlings in the sand growing medium manifested greater response to leonardite additions than those grown in the sand-peat mixture. However, unlike zinnia seedlings, marigold seedlings would be expected to exhibit greater growth at optimal leonardite levels in the sandpeat mixture than in sand only.

Marigold transplants. The addition of fertilizer to sand and sand-peat growing medium without leonardite increased marigold transplant growth greatly (Table 2).
Height increased $204 \%$ and $56 \%$, fresh shoot weight increased $2357 \%$ and $620 \%$, fresh root weight increased $1733 \%$ and $475 \%$, dry shoot weight increased $1590 \%$ and $531 \%$, and dry root weight increased $1033 \%$ and $300 \%$ for sand and sand-peat media, respectively.

Total stem length, fresh shoot weight, and dry shoot weight of marigold transplants grown in sand or sand-peat media increased as the amount of leonardite increased up to $6.25 \%$ and then declined for $12.5 \%$ leonardite (Fig. 5). Fresh root weight of marigold transplants grown in the sand medium followed a similar pattern of response, while fresh root weight declined with leonardite additions to the sand-peat medium. Leonardite had no effect on dry root weight of marigold transplants grown in either medium. Optimal leonardite levels for the sand medium ranged from 5.1 to 7.2 and for the sand-peat medium ranged from 6.3 to 7.0. Compared to marigold seedlings grown in sand, marigold transplants have a lower optimal level of leonardite. Based on fitted equations for the sand medium, optimal leonardite levels
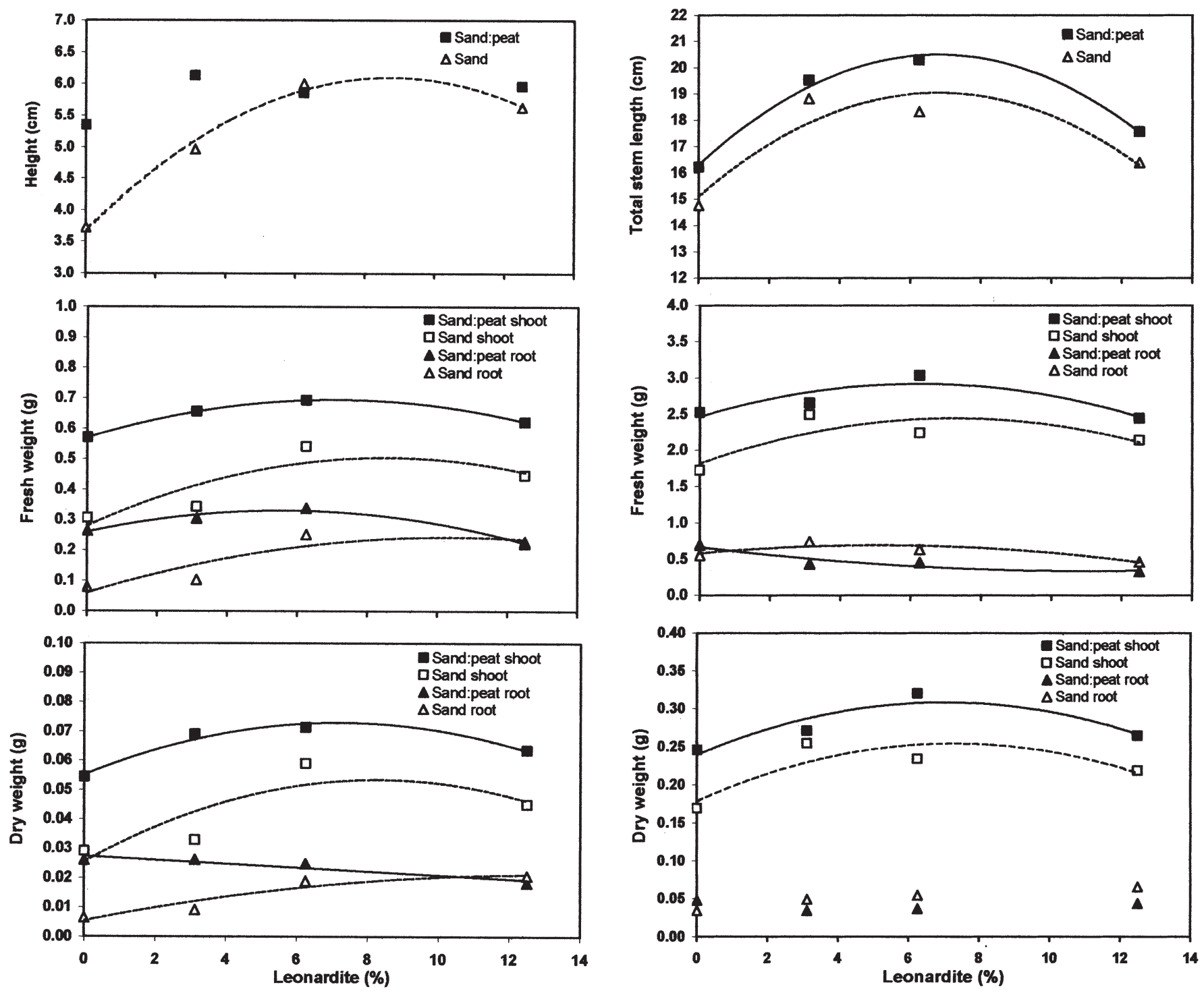

Fig. 4. Effects of Utah-mined leonardite on height, fresh shoot and root weight, and dry shoot and root weight of marigold seedlings in a sand or a 1 sand : 1 peat (by volume) growing medium with fitted linear or quadratic relationships when $P<0.05$, otherwise lines are not shown.

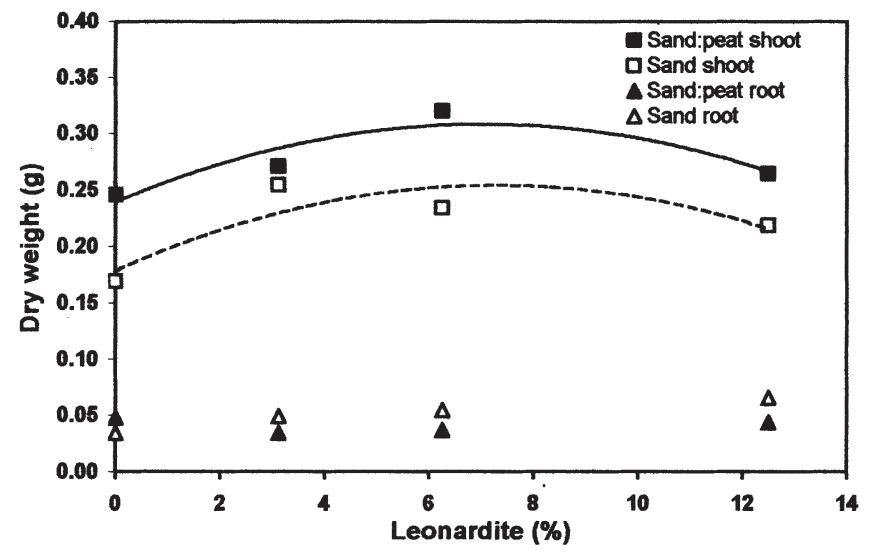

Fig. 5. Effects of Utah-mined leonardite levels on height, fresh shoot and root weight, and dry shoot and root weight of marigold transplants in a sand or a 1 sand : 1 peat (by volume) growing medium with fitted quadratic relationships when $P<0.05$, otherwise lines are not shown. 
would be expected to increase height $26 \%$, fresh shoot weight $34 \%$, fresh root weight $19 \%$, and dry shoot weight $44 \%$ compared to no leonardite. For the sand-peat growing medium, increases of $26 \%$ for height, $18 \%$ for fresh shoot weight, and $29 \%$ for dry shoot weight would be expected at optimal leonardite levels. Fitted quadratic models adequately characterized $\left(r^{2}=0.65-0.99\right)$ the effect of leonardite on marigold transplant growth. Shoot growth of both sand and sand-peat grown marigold transplants continued to benefit from leonardite additions as was observed for marigold seedlings, but root growth of marigold transplants was less affected.

\section{Conclusions}

Overall, when combined with fertilizer application, zinnia and marigold seedlings and transplants responded favorably to leonardite additions up to $6.25 \%$ and then response declined. Reduced growth associated with high humic substance levels is often attributed to reduced micronutrient availability to plant roots, possibly due to: 1) excessive ligands (Ayuso et al., 1996; Rauthan and Schnitzer, 1981); 2) physical properties of the medium becoming unfavorable for growth; or 3) both. For a Utah-mined leonardite, optimal zinnia growth would be expected using $7.5 \%$ leonardite in a sand medium for seedlings and $8 \%$ leonardite in a sand-peat medium for transplants. A sandpeat medium with $7 \%$ leonardite should be optimal for growing marigold seedlings and transplants. Leonardite enhanced growth possibly by increasing cation exchange capacity or otherwise enhancing nutrient uptake. Leonardite also provides WEFA in the media solution, which may directly influence plant growth (Vaughan and Ord, 1981; Fuehr and Sauerbek, 1967).

Future research could examine the container leachate to quantify the amount of HA/FA compounds lost in the leachate and assess the retention rate of these organic compounds in the root zone. Furthermore, because responses differed between species, further studies with additional species are warranted. Additional information about leonardite's utility as a media amendment could be provided from studies that varyfertilizer and leonardite levels. Since leonardite sources differ, additional studies must include detailed characterization of the leonardite materials employed so that specific recommendations can be made.

\section{Literature Cited}

Adani, F., P. Genevini, P. Zaccheo, and G. Zocchi. 1998. The effect of commercial humic acid on tomato plant growth and mineral nutrition. J. Plant Nutr. 21:561-575.

Ayuso, M.T. Hernandez, C. Garcia, and J.A. Pascual. 1996. Stimulation of barley growth and nutrient absorption by humic substances originating from various organic materials. Bioresource Technol. 57:251-257.

Brownell, J.R., G. Nordstrom, J. Marihart, and G. Jorgensen. 1987. Crop responses from two new leonardite extracts. Sci. Total Environ. 62:492-499.

Bryan,H.H. 1976. Response of tomatoes to seed and seedling applications of humates and alpha-keto acids. Proc. Florida State Hort. Soc. 89:87-90.

Chen Y. and T. Aviad. 1990. Effects of humic substances on plant growth, p. 161-186. In: P. MacCarthy, C.E. Clapp, R.L. Malcolm, and P. R. Bloom (eds.). Humic substances in soil and crop sciences: Selected readings. Amer. Soc. Agron.Soil Sci. Soc. Amer., Madison, Wisc.

David, P.P., P.V. Nelson, and D.C. Sanders. 1994. A humic acid improves the growth of tomato seedlings in solution culture. J. Plant Nutr. $17: 173-184$.

Duplessis, G.L. and A.F. MacKinzie. 1983. Effect of leonardite applications on phosphorous availability and corn growth. Can. J. Soil Sci. 63:749-751.

Fuehr, F. and D. Sauerbek. 1967. The uptake of colloidal organic substances by plant roots, as shown by experiments with ${ }^{14} \mathrm{C}$ labeled humus compounds, p. 317-328. In: Isotopes in plant nutrition and physiology. Intl. Atomic Energy
Agency, Vienna, Austria.

Jackson, W.R. 1993. Humic, fulvic, and microbial balance: Organic soil conditioning. Jackson Research Center, Evergreen, Colo.

MacCarthy, P., R.L. Malcolm, M.H.B. Hayes, R.S. Swift, M. Schnitzer, and W.L. Campbell. 1981. A collection of standard humic substances established in 1981. Site accessed 10 Sept. 2002. $<$ http://www.ihss.gatech.edu/>

O'Donnel, R.W. 1973. The auxin-like effects of humic preparations from leonardite. Soil Sci. 116:106-112.

Pertuit, A.J., J.B. Dudley, and J.E. Toler. 2001. Leonardite influences tomato seedling growth. HortScience 36:913-915.

Rauthan, B.S. and M. Schnitzer. 1981. Effects of a soil fulvic acid on the growth and nutrient content of cucumber (Cucumis sativus) plants. Plant Soil. 63:491-495.

Reynolds, A.G., D.A. Wardle, B. Drought, and R. Cantwell. 1995. Gro-Mate soil amendment improves growth of greenhouse-grown 'Chardonnay' grapevines. HortScience 30:539-542.

Schnitzer, M. 1982. Organic matter characterization, p. 581-594. In: A.L. Page (ed.). Methods of soil analysis, part 2. Chemical and microbial properties, 2nd ed. Amer. Soc. Agron.-Soil Sci. Soc. Amer., Madison, Wisc.

Schnitzer, M. and M.U. Khan. 1972. Humic substances in the environment. Marcel Dekker, New York, N.Y.

Tan, K.H. and V. Nopamornbodi. 1979. Effect of different levels of humic acids on nutrient content and growth of corn (Zea mays L.). Plant Soil 51:283-287.

Tao, S. and B. Lin. 2000. Water soluble organic carbon and its measurement in soil and sediment. Water Res. 34:1751-1755.

Vaughan, D. and R.E. Malcolm. 1985. Influence of humic substances on growth and physiological processes, p. 37-75. In: D. Vaughan and R.E. Malcolm (eds.). Soil organic matter and biological activity. M. Nijhoff/W. Junk, Publishers, Dordrecht, The Netherlands.

Vaughan, D. and B.G. Ord. 1985. Soil organic matter A perspective on its nature, extraction, turnover, and role in soil fertility, p. 1-35. In: D. Vaughan and R.E. Malcolm (eds.). Soil organic matter and biological activity. M. Nijhoff/W. Junk Publishers, Dordrecht, The Netherlands. 